\title{
La risa de fuego: Un análisis antropológico sobre el papel trasgresor del fuego en la creación artística
}

\section{Fire's Laugh: An Anthropological Study on Fire's Role in the Artistical Creation}

\author{
JAIME REPOLLÉS-LLAURADÓ \\ Escuela Contemporánea de Humanidades de Madrid. \\ Centro de Estudios Superiores Felipe II. Universidad Complutense de Madrid. \\ jaime_repolles@hotmail.com \\ Vicente Alemany SÁnchez-Moscoso \\ Escuela Contemporánea de Humanidades de Madrid. \\ Centro de Estudios Superiores Felipe II. Universidad Complutense de Madrid. \\ jaime_repolles@hotmail.com.
}

Recibido: 4 de diciembre de 2012

Aprobado: 20 de febrero de 2013

\section{Resumen}

El fuego juega un papel fundamental en numerosas manifestaciones artísticas, así como en diversos procedimientos pictóricos, escultóricos y gráficos. El elemento ígneo acompaña al artista en la "cocina de la pintura", en las fraguas de los escultores y es un elemento esencial para diversas técnicas de dibujo y grabado convirtiéndose en el más activo agente catalizador de las trasformaciones sustanciales propias de la expresión plástica. Además de este papel instrumental, el significado del fuego -sus implicaciones simbólicas y culturales- cobran aún más relevancia cuando nos aproximamos al fuego desde su dimensión antropológica. La mitología grecolatina, las múltiples culturas primitivas y la tradición cristiana acuden al fuego para describir trasformaciones míticas, metamorfosis elementales, purificaciones de la naturaleza y desastres del hombre. Es un elemento espiritual y tecnológico, cuyas máximas manifestaciones actuales perviven en las fiestas populares como las Fallas o las celebraciones de Carnaval. Podemos considerar el fuego como metáfora de la creación artística en la actualidad.

Palabras clave: fuego, carnaval, arte contemporáneo transgresor.

Repollés-Llauradó, J., Alemany Sánchez-Moscoso, V. (2013): La risa de fuego: Un análisis antropológico sobre el papel trasgresor del fuego en la creación artística. Arte, Individuo y Sociedad, 26 (1) 101-115 


\begin{abstract}
Fire plays a foundational role in several artistic fields, as well as in different pictorial, sculptural and graphic techniques. The igneous element accompanies the artist at the "painting kitchen", in the carvers' forges and it is also an essential element for a number of drawing and engraving techniques. It is the most active catalyst agent for the substantial transformations characteristic of plastic expression. In addition to this instrumental role, the meaning of fire -its symbolic and cultural implications- becomes even more relevant as we approach fire from its anthropological dimension. Greco Latin mythology, several primitive cultures, as well as the Christian tradition, use the fire to describe substantial transformations, elemental metamorphosis, nature purifications and human disasters. Fire is a spiritual and technological element, whose biggest present manifestations still remain in popular celebrations as the Fallas or Carnival celebrations. We can take fire as a metaphor of present art creation.
\end{abstract}

Key words: fire, carnival, contemporary transgressive art.

Repollés-Llauradó, J., Alemany Sánchez-Moscoso, V. (2013): Fire's Laugh: An Anthropological Study on Fire's Role in the Artistical Creation. Arte, Individuo y Sociedad, 26 (1) 101-115

Sumario: 1. En el principio, el fuego mítico, 2. La infame domesticación del fuego, 3. La herejía medieval del fuego, 4. El fuego como catalizador cultural, 5. El Carnaval y las llamas de la purificación, 6. El fuego grotesco y lo abyecto, 7. Fuego romántico, alquimia y resentimiento, 8. La quema y el entierro de la sardina, 9. Las cenizas de la trasgresión, 10. La risa del fuego. Referencias.

\title{
1. En el principio, el fuego mítico
}

El fuego habla. Es muy precisa la lengua cuando dice que el fuego surge declarándose. La tierra de labranza se abre, el agua de manantial brota, el aire sopla con los vientos, pero los incendios se declaran. El fuego y la palabra son, por tanto, expresiones que se dieron juntas en el principio, según la mitología de la religión, pero también de la ciencia. Ya comenzara el mundo con la sublime entonación del Verbo o gracias a la tronadora explosión del Big Bang, ambos elementos genésicos estaban ligados por el mismo sentido performativo de la declaración.

En las sociedades arcaicas, los mitos eran a menudo contados a la lumbre del fuego. Los narradores míticos hacían crepitar sus palabras acompañados por las llamas, avivando su incontinencia verbal con el mismo furor con que caldeaban la imaginación de sus oyentes, los mitómanos. Es fácil imaginar a Homero declamando su largo poema en la noche de los tiempos, al calor de una hoguera. Seguramente los primeros versos de la Ilíada, en los que se apela a la célebre Musa, irrumpieron como flamas en la mente del rapsoda, pues ¿no recuerda la Musa aquella cólera de Aquiles "que acabará inflingiendo a los aqueos mil dolores, y muchas almas de héroes esforzados precipitó al Hades”? (Homero, Ilíada, Canto I, 1- 5) ¿No anticipa esta Musa el resentimiento moral de los combatientes griegos y, como consecuencia de tanto ardor, la ulterior quema de Troya? 


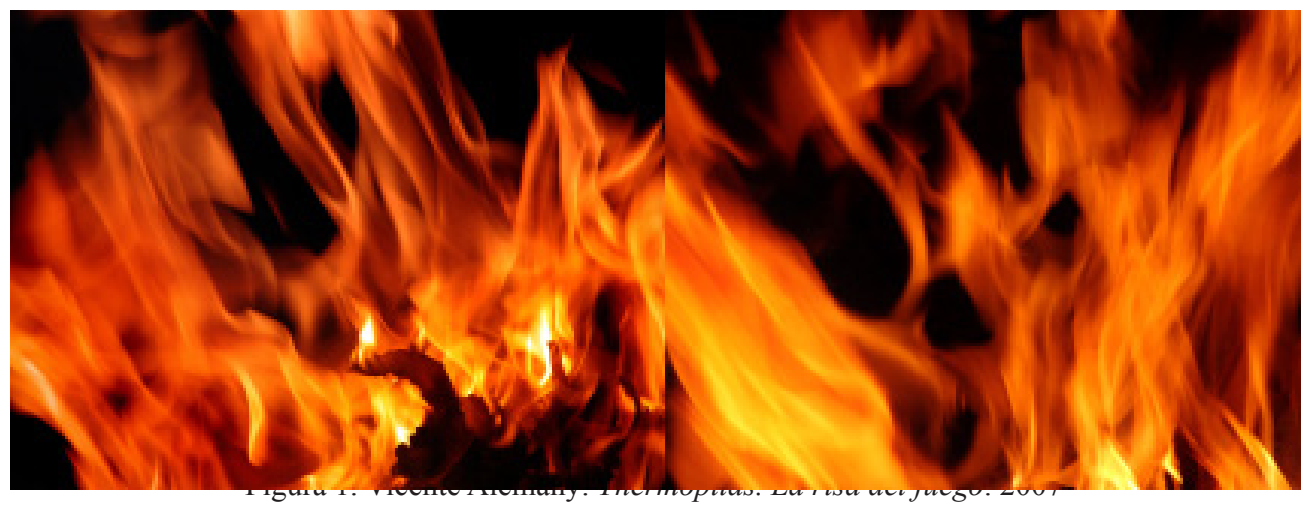

Sin duda, Homero hizo un uso poético del imaginario del fuego, pero también parece que la ardiente Musa poseyó al aedo, se declaró a través de él, incendiando todos sus versos con abrasivas metáforas. Sorprende el modo como el poeta, arrebatado por esta Musa Pirómana, ligó imágenes tan dispares como la cólera de Aquiles, la forja de su escudo en la fragua de Hefesto, la cremación de Héctor y el incendio de Troya, por una propagación literaria. Las propiedades físicas del fuego -cálido, seco y ligero- son también las características morfológicas de Aquiles, un joven de largo cabello rubio y flameado, tan ardiente en el campo de batalla como seco en el amor, tan ágil en combate que lleva el sobrenombre de el de los pies ligeros. Pero además, al igual que la antigua medicina hipocrática, Homero asoció el fuego al temperamento colérico del rey de los mirmidones, y éste al ardor de estómago, causado por la acidez de la bilis.

Si el fuego es la causa material de la cólera de Aquiles, y de la guerra de Troya, también es la luz que dora la piel del guerrero, bañado de inmortalidad -al menos, hasta los talones- en la laguna Estigia. Esta perennidad del héroe es tan difícil de extinguir como la combustión de la Musa del fuego. Pero Aquiles no es el único personaje homérico modelado según las propiedades de un elemento natural. La Odisea es un ecosistema rico en imaginarios de Ninfas, Sirenas o Náyades, todas ellas Musas acuáticas que se cruzan en el camino de Ulises provocándole mil demoras. Hay quien asegura, como el escritor Patrick Harpur, en El fuego secreto de los filósofos (Harpur, 2005) que las verdaderas fuentes de la mitología son, en realidad, estos espíritus feéricos, llámense musas, hadas o ninfas, que emanan de los elementos naturales y que han sido denominados, por toda una tradición exotérica, geniecillos del lugar (genii loci). La rapsodia y las artes clásicas no cesaron de descubrir estos seres encantados entre las cualidades materiales de las cosas, y los poetas se ayudaron de ellos para perfilar los rasgos de muchos caracteres mitológicos.

Harpur asegura que los personajes míticos eran tan sólo elementos físicos, debidamente encarnados por figuras alegóricas que señalaban a los hombres los lugares sagrados de la naturaleza. Pero muy pocos mitos cuentan el camino inverso, es decir, el modo según el cual los dioses se convierten en naturaleza para mostrar a los hombres los sinsabores de la civilización. Dentro de este segundo tipo de mitología, digamos ecológica, destaca la fábula de Prometeo, quizá la más lúcida 
transformación del fuego sagrado de los tiempos míticos en calor humano. Según Hesiodo, Prometeo opera una distinción fundamental entre el fuego divino (el fuego santuario que sirve, como las palabras, para orar) y el fuego humano (el calor que sirve para cocinar) prendiendo la mecha emancipadora de la humanidad sobre el Estado de Naturaleza recreado en los mitos.

Es sabido que la mitología y la rapsodia griegas muestran a los dioses como hombres. Los dioses áticos participan en la guerra, explotan la naturaleza, controlan los elementos o se inmiscuyen en la historia charlando con los humanos. Prometeo roba al padre Zeus una llama del fuego sagrado, apartando su empleo del holocausto y del sacrificio, precisamente para concedérsela a los humanos en forma de fuego de cocina. El fuego de sacrificio, que antaño ardía en las piras de los templos quemando los huesos y la grasa no comestible de los animales, provocaba una enorme humareda que ascendía hasta el cielo y sustentaba la etérea necesidad de los dioses con cenizas aromatizadas. Todo esto sucede porque, un mal día, el gigante mítico engañó a Zeus, dejándole en sacrificio una cáscara burlesca de piel y grasa: una ofrenda sin carne, únicamente sostenida por la hueca osamenta. La trasgresión prometeica no quedará exenta de sanción, tanto para el gigante mítico como para la humanidad. Este hurto estará ligado a un agravio nefasto contra los dioses: Prometeo se ríe de Zeus, y por ello será encadenado a una roca y brutalmente atacado por un ave rapaz. Pero este martirio devendrá pronto infernal -como los de Sísifo o Tántalo- pues el águila se comerá el hígado del héroe encadenado cada día, que volverá a surgir de nuevo, para secretar más bilis, y ser nuevamente devorado. De modo que el mismo órgano que encolerizó a Aquiles amargará el suplicio de Prometeo, como si el castigo divino contra la risa fuera el derrame eterno de bilis amarilla.

\section{La infame domesticación del fuego}

Si en la mitología el fuego sagrado se opone al fuego profano es porque la risa de los hombres sofoca la cólera de los dioses. Las deidades sobrevivirán mientras existan mitos que declarar, mientras haya fuego que consagrar. Gracias a la invención del fuego y la escritura, la civilización terminó con los tiempos míticos -tantas veces confundidos con el Paraíso- pero los mitos aún persisten gracias al simple fuego de cocina. En efecto, las Musas se habrían extinguido del todo, junto con el relato oral, si no fuera porque la técnica somete a fusión (y fisión) las fuentes de energía naturales y, por lo tanto, agita permanentemente los seres feéricos que, según Harpur, habitan la naturaleza. Quizá por esto, en las sociedades primitivas existen tantos mitos fundacionales (o sagrados) sobre el origen del fuego como mitos instrumentales (o técnicos) sobre los modos de dominarlo y conservarlo activo.

En efecto, cada cultura tiene su peculiar mito prometeico, es decir, su relato sobre la adquisición y posterior mantenimiento de la primera llama. Pero ya aparezca ésta en forma de rayo, de incendio, o por el simple frotamiento de dos palos, la chispa del fuego profano trae consigo las invenciones técnicas de la cocina, la cerámica, la metalurgia, la industria y, por ello, la primera conciencia de la pérdida del Estado de Naturaleza. Sólo en la ignorancia del castigo advenido a Prometeo, los primitivos creen que el fuego humano es un regalo caído del cielo. El insigne mitógrafo James G. Frazer recopiló en sus Mitos sobre el origen del fuego (Frazer, 1930) multitud de 
historias tribales de Asia, África, América, Australia y las Islas del Pacífico en torno al descubrimiento del fuego y la manera de mantenerlo. Los nativos cuentan miles de historias fabulosas sobre ancestros que arrebataron una llama al Sol, ya fuera clavándole una flecha cogida por una cuerda o mediante una expedición insólita al lugar donde el Astro Rey se funde con el horizonte. Tras estudiar en profundidad relatos como éstos, Frazer concluyó que existen tres edades de la mitología del fuego: la edad sin fuego, la edad del fuego empleado, y la edad del fuego encendido.

A juzgar por la primera edad del fuego, los hombres primitivos eran como animales desconocedores del poder de las llamas, que comían carne cruda o calentaban sus alimentos exponiéndolos al Sol; la humanidad permaneció en este estado salvaje hasta que supo emplear el fuego para su beneficio, ya fuera éste encontrado por azar, o cedido por un animal mítico, sin saber todavía cómo provocarlo ni mantenerlo. No en vano, muchas comunidades creen haber recibido el fuego regalado por alguna especie animal, la mayoría de las veces un pájaro o un ser sobrenatural, desde entonces considerado como pieza tabuada de caza; finalmente, los hombres accedieron a la civilización propiamente dicha, la Edad del Fuego, cuando supieron aplicar cabalmente las destrezas pirotécnicas del alumbrado y su conservación. Pero ¿no se le escapó a Frazer una cuarta edad del fuego, que pasaría por el pleno dominio de la pirotecnia? ¿No existe una conciencia del fuego como arte, el fuego fatuo, emancipado del ámbito sagrado, pero también del culinario y del industrial, para servir de placer estético y divertimento? ¿De existir esta época, no sería una regresión al fuego sagrado? No exactamente: más bien todo lo contrario, una trasgresión del valor sagrado del fuego.

\section{La herejía medieval del fuego}

En su empeño por estudiar las bases biológicas de todo imaginario, el sociólogo Roger Caillois explicó que lo sagrado suscita en el fiel los mismos sentimientos antagónicos que el fuego en el niño: el mismo temor de quemarse, el mismo afán de encenderlo (Caillois, 1996). El fuego sacro será siempre una llama de orden religioso, un medio de acceso a los dioses mediante inmolación animal, un elevador del alma, un purificador de la materia. Modelo de luz divina para Occidente, irradiación basada en el esplendor moral y la aspiración ultramundana de las religiones gnósticas, el fuego sacro ha sido siempre extraído de un mundo abstracto, de energías puras y limpias, de elementos naturales intactos, invocado a menudo por un sacerdote entregado al culto de un dios ascético; todo lo contrario que el fuego profano, surgido de un mundo concreto, de substancias carnales y malignas, de elementos mezclados, provocado en el laboratorio por un oscuro brujo alquimista, a veces inspirado por sus tratos con el diablo.

Luego la cuarta edad del fuego tendría necesariamente un origen propio, y hasta sus exclusivos sistemas de inflamación. El fuego fatuo debió nacer, con toda probabilidad, en la oscura Edad Media, fue engendrado tanto por los alquimistas como por la cultura popular que participó en los festejos de Carnaval, y ha sido alimentado hasta hoy con el perverso carburante de la risa. Esta es la razón por la que el fuego de Carnaval está presente durante las misas negras que tienen lugar todos los años, entre finales de enero y principios de marzo, precisamente en el periodo 
de transición desde el comienzo de Cuaresma hasta Semana Santa. El miércoles de Ceniza se celebra la mayor trasgresión de la eucaristía, La quema de la Sardina, donde el pueblo funde la mitología del fuego profano con el sacrilegio prometeico.

Aunque existen varias etimologías de la palabra Carnaval, la acepción en latín vulgar se refiere al periodo de privación cárnica de Cuaresma, carnelevare, de carnelevare (abandonar la carne) todo lo contrario del italiano carnevale, de carne-vale (se puede comer la carne) que hace referencia a la misma interdicción, pero al revés. En cualquier caso, ambas raíces explican la fiesta popular como una imposición y una liberación, al mismo tiempo, del tabú de la carne. El Carnaval, por tanto, es el festejo en el que los cristianos dejan de sacrificar y consumir animales, pero se entregan a la fogosidad de los cuerpos, al fuego que antecede a la Pasión.

Muchas normas sociales se tornan comprensibles en sus periodos de suspensión. En este sentido, la antropología no ha cesado de interesarse por la fiesta de Carnaval, un espacio de permisividad controlada durante el cual las costumbres populares acceden a un verdadero estado de excepción. Como el tabú del incesto o el tabú de los muertos, el tabú de la carne carnavalesco ha sido de gran interés para el estudio de la moral popular, pues la existencia de prohibiciones en el seno de la baja cultura es un claro indicio de la existencia de leyes en el seno de la naturaleza. Caillois explicó que sólo el mayor sacrilegio, "la mayor infracción de la más santa de las leyes, otorga al hombre el peligroso concurso de las fuerzas naturales" (Caillois, 1996, p. 46). El hombre hubo de conocer el pecado para acceder a las fuerzas demoníacas del medio ambiente. Es necesario aliarse con el mal y la trasgresión para descubrir el potencial afirmativo de la naturaleza. Las ciencias positivas son hijas del pecado. Luego el tabú de la carne, muy ligado en Carnaval al tabú del fuego, es también una herejía popular que mancilla la eucaristía precisamente para dominar el elemento ígneo. El uso del fuego liberado de todo rito, de toda moral, desmitifica por fin la pirotecnia.

Esta paradoja es tan antigua como el Génesis, y fue la obsesión del antropólogo Claude Lévi-Strauss, pionero de la mitología comparada, quien se dedicó con ahínco a comprender el vínculo estructural entre la cultura y la naturaleza, a partir de la ley. En efecto, al presentar los mitos primitivos como supuestos programas legislativos de las costumbres de los nativos, Lévi-Strauss logró decodificar el pensamiento salvaje en una serie de prohibiciones alimenticias -los llamados tabúes- debidamente asociados a las normas sociales de determinados clanes. Antecedentes directos de las reglas civilizadas, los tabúes imponían todo tipo de restricciones al consumo de ciertas especies animales, cuya carne no podía ser digerida so pena de castigo.

\section{El fuego como catalizador cultural}

La originalidad de Lévi-Strauss fue comprender los entresijos de esta moralidad a partir de un sentido culinario de la cultura, siempre según la vara de medir del fuego. En efecto, el mitólogo hizo del elemento ígneo el protagonista de sus Mitológicas, 1964-1971, dada su participación en la cocción de la carne, pues el acceso a la cultura (lo cocido) como superación del estado salvaje (lo crudo) siempre corre el riesgo de estropear la carne (lo podrido). Por consiguiente, en la cosmovisión de Lévi-Strauss, el fuego facilita la cultura (la cocina) asando los alimentos y permitiendo al hombre digerir la naturaleza sin riesgo de putrefacción. En este sentido, el mitoanálisis 
establece los límites termodinámicos que el elemento ígneo impone a los estados de la carne, pues la carne sin fuego, o carne cruda, se califica como salvajismo, mientras que el fuego sin carne, el fuego sagrado, es signo de divinidad. Entre ambos estados extremos, late la carne humana, demasiado humana, siempre debatida entre lo frío (la carne podrida, descompuesta) o lo caliente (la carne quemada, chamuscada).

Existe, por tanto, una relación antropológica entre el fuego de cocina y la cultura, así como, en la mitología, existe una relación metafísica entre el fuego místico y la palabra. Estas correspondencias se cruzan en el cristianismo, que funde palabra y cocina en la Eucaristía, o palabra y fuego en la Zarza Ardiente. Aunque esto no es exclusivo del cristianismo. El presocrático Heráclito concedió un papel estelar al fuego en la creación, asegurando, con este principio material (arché), la energía de su adagio más conocido: todo fluye (Panta Rei) el mundo se agita en metamorfosis continuas que hacen que las cosas se conviertan en sus contrarias. Para el filósofo de Éfeso la guerra es la madre de todas las cosas, luego fuego y guerra están conectados en el principio, así como lo estaban para Homero, cuya tragedia originaria es, sin duda, la guerra, y para los cristianos, que desviarán inmediatamente el drama bélico hacia el pecado.

El gran estudioso de la retórica de los elementos materiales de los presocráticos, Gaston Bachelard, comenzó su Psicoanálisis del fuego, 1938, insistiendo en la capacidad de éste para asumir netamente valoraciones contrarias: "Brilla en el Paraíso. Arde en el Infierno. Es dulzura y tortura. Cocina y Apocalipsis" (Bachelard, 2005 , p. 23). Esta es la razón por la que el fuego tiene la exclusiva del elemento del $\mathrm{mal}$, a pesar de lo perniciosa que pueda ser el agua, la tierra o el aire en exceso. El fuego hace posible la cocción de la carne animal, la degustación de la naturaleza, pero también echa a perder el Paraíso, abrasándolo. Es por esto que el elemento heracliteano ha servido a paganos y cristianos para sancionar el consumo indebido: el conocimiento prohibido. Las cenizas son vanitas que recuerdan el paso de la ciencia por la naturaleza y, en definitiva, el paso de la moralidad del hombre por el mundo, que todo lo destruye. La cultura estigmatiza al fuego, su precursor, como un excedente diabólico, de la misma manera que Cristo se encara al diablo en el desierto como quien se enfrenta a un espejo perverso: el Anticristo.

Pero además de arder en el infierno y abrasar a los condenados, el fuego purifica los lugares sagrados; sus llamas despejan el territorio de la comunidad donde se instala la catedral, el templo o el tótem; y, como bien recordó Freud, el tótem sólo se alza para imponer un tabú (Freud, 1996). No hay prescripción sin prohibición, ni lugar sagrado sin mácula. Por ello, la cultura cristiana ha hecho del fuego, el tabú del pecado de la carne: a lo mejor porque la chispa del fuego, en el amanecer de la técnica, se debió al frotamiento de dos cuerpos entre sí. Por ello, esta trinidad maldita del fuego, la carne y el pecado ha generado un antihéroe bien distinto del guerrero mítico, el asceta cristiano, quien aumenta su poder en la medida que disminuye sus roces con otros, para aproximarse tan sólo a Dios.

\section{El Carnaval y las llamas de la purificación}


Efectivamente, Caillois explica el ascetismo precisamente por la renuncia, que está ligada a la represión de la carne y del pecado, pero, en última instancia, a la producción de un exceso de resentimiento, el melancólico fuego interior (Caillois, 1996, pp. 2227). En este sentido, el filósofo José Luis Pardo aclara que es tan inhumano comer la carne (cruda) sin fuego (artificial) como acceder al fuego sin carne (Pardo, 1997). El fuego ascético de la religión ha consumido el cuerpo de los místicos durante siglos, haciendo levitar sus almas inmoladas como los antiguos aromas etéreos de la quema santuaria. El fuego sin carne, dice Pardo, "ese fuego interno que depura la carne del que se niega a comerla es inhumano, es fuerza sobrenatural, motor de divinización" (Pardo, 1997, p. 24). Tan inhumana es la carne cruda de los caníbales como el fuego descarnado de los ascetas. De ahí que la Iglesia haya tenido que permitir el Carnaval -donde los cuerpos se apegan más que nunca al elemento tierra-para suspender por momentos el inhumano régimen ascético del fuego sin carne: esa frugalidad absoluta que eleva el alma sobre un cuerpo disminuido, reducido a su mínima expresión.

No es casual que el Carnaval sea un festejo sólo vigente en culturas católicas. El catolicismo garantiza el perdón universal de los pecados, concediendo cierto relax a sus fieles, en comparación con el puritanismo protestante. Con el Carnaval el católico accede, durante un tiempo breve, a la carne fogosa del populacho, guiado por los principios de lo bajo y lo inferior, allí donde se producen los esponsales paganos entre el mito prometeico (origen del tabú del fuego) y el mito cristiano (origen del tabú de la carne). La baja cultura del imaginario católico y la mascarada barroca del Carnaval consienten una liberación del ascetismo, y los creyentes, que sufren durante las fiestas metamorfosis de signo herético, pueden, al fin, perder la identidad, e ingresar en la dynamis inconsciente de la materia, acelerada por la termodinámica de los cuerpos.

En su estudio clásico sobre La cultura popular en la Edad Media y el Renacimiento, 1965, el crítico literario soviético Mijail Bajtin estudió el modo como el Carnaval es una trasgresión de los cultos y jerarquías establecidos por la sociedad feudal. Su análisis de la cultura popular medieval permanece intacto en la sociedad capitalista, que sufre también los rigores del puritanismo protestante. Bajtin define el Carnaval como "la segunda vida del pueblo, basada en el principio de la risa" (Batjin, 2005, p. 14). En efecto, la risa es el engrudo que une a los individuos para conformar la voz unánime del pueblo, es la chispa que enciende la llamarada contagiosa que muchos denominan Risa Pascual (risus paschalis). En consecuencia, el carburante de la desacralización del fuego, su principio perverso de combustión, es la risa, el sarcasmo, la bufonada, que resuenan en las carcajadas del pueblo durante las fiestas.

Esta es la razón por la que el folklore antiguo hizo protagonista al fuego en el rito de la Quema de la Sardina. El Carnaval es el reino de la artificiosidad, por no decir la mentira, del pecado y, por extensión, de la máscara, de las metamorfosis salvajes. Es el tiempo en el que el fuego recobra su origen bestial, es decir, su incubación salvaje y su posterior donación a la humanidad por parte de un animal mítico. Es tan notable el origen animal del fuego, que la propia genealogía grecorromana de los trabajadores del fuego se funde con los lobos (Repollés, 2011). Según la mitología, Hefesto-Vulcano, el semidiós de la fragua, era un herrero poco agraciado, cojo, 
contrahecho y de origen bastardo, que fue abandonado a temprana edad por los dioses para ser criado entre lobos. El origen salvaje de Vulcano hizo que fuera considerado un advenedizo entre los Olímpicos, quienes le hicieron objeto de sus burlas por las infidelidades de Venus, su esposa, con Marte. Para colmo de males, Vulcano trabajó siempre como un esclavo, penosamente guarnecido en una cueva primitiva, por lo que es difícil encontrar un ser mítico más vejado; un obrero tan desdichado como el artesano medieval sin amparo del gremio, un trabajador manual sin los derechos y libertades que gozaban el resto de los dioses.

En resumidas cuentas, la baja mitología del fuego profano cuenta primero la manera como Prometeo donó a la humanidad el más preciado de los elementos, el fuego de cocina, que Vulcano, en segundo lugar, trabajó como una obra de arte con la maña de los artistas del fuego (alfareros, herreros, vidrieros, etc.). Fue preciso que el gigante Prometeo bajara a la tierra una flama para constituir el fuego fatuo, que Vulcano hizo chisporrotear en su gruta industrial, en el vientre de la tierra, en forma de herrumbre escoriada. Pero sucedió una tercera mutación del fuego sagrado en la Edad Media, cuando la masa incandescente de Vulcano salió a la superficie durante los festejos de Carnaval, haciéndose pública y compartida por el populacho, alimentándose con la algarabía y la risotada: incubado en lo profundo de la gruta y eructado por la garganta del pueblo apareció el fuego grotesco.

\section{El fuego grotesco y lo abyecto}

El fuego sagrado desciende de los cielos para narrar la caída de los dioses, mientras que el fuego grotesco emerge de la tierra para eructar las bajas pasiones del inconsciente colectivo. Seguramente el autor que mejor ha expresado esta erupción magmática y gutural del fuego ha sido François Rabelais, maestro de la comedia del siglo XVI, quien rebajó la épica literatura medieval al chiste popular y la bufonada carnavalesca. Cuando Rabelais escribió Gargantúa y Pantagruel, 1533-35, agregó los géneros míticos de la epopeya y gigantomaquia para narrar las andanzas de una estirpe de gigantes golosos, empleados por los hombres como máquinas de guerra, que no paraban de beber, comer, devorar libros eruditos, eructar, ventosear, defecar y blasfemar. No hay institución del mundo feudal sobre la que Gargantúa o Pantagruel (cuyos nombres guturales resuenan a todo caótico) hayan obrado una infame deposición (intestinal) o proferido una blasfemia (biliosa).

Si la gigantomaquia de Hesíodo dispone a Prometeo mancillando los rituales sagrados, la de Rabelais pinta el más completo fresco herético de la sociedad medieval. El fuego también está muy presente en Rabelais, pero sobre todo la cólera, asociada a la mala digestión estomacal, a la incontinencia humoral y a las bajas pasiones de los gigantes. Estas características biliosas perfilan los rasgos dicharacheros de los corpulentos antihéroes, siempre enmarcados por un ambiente bélico y festivo, de tal manera que su lenguaje, rico en citas populares e imágenes carnavalescas, expresa a la perfección el espesor grasiento del fuego grotesco: el magma volcánico y subterráneo que todo lo devora, reduciendo todo a cenizas mientras eructa gases pestilentes.

Sucede que el fuego -seco, caliente y ligero- se precipita en el elemento inverso, la tierra -húmeda, fría y pesada- mediante una transfiguración grotesca, como si el 
temperamento colérico de Aquiles se hubiera espesado en la grasienta melancolía de Gargantúa. Esta depravación del fuego heroico en excremento magmático es muy sensible en el parto del gigante. Cuenta Rabelais que las comadronas de Gaznachona, su madre, "descubrieron unos pellejos de gusto desagradable, y pensaron que era el niño; pero era el fundamento que se le escapaba, por relajación de intestino recto, por culpa del exceso de callos que había engullido" (Rabelais, 1999, p. 87).

¿Cómo es posible que el fuego de Marte y el imaginario colérico de los antiguos griegos hayan producido esta variante inmunda y coprológica en la Edad Media? Lévi-Strauss hubiera dicho que los excesos alimenticios, culturales y guturales de los gigantes de Rabelais, así como de los fastos medievales, impidieron digerir la carne, transmutándola en una masa diarreica y putrefacta. Si tradicionalmente contra la putrefacción se había luchado gracias a la purificación del fuego, el imaginario grotesco, surgido del bajo vientre y entumecido en aguas cenagosas y atrabiliarias, se alimenta de la descomposición. Los excrementos (putrefactos) o los vómitos (biliosos) son erupciones volcánicas que todo lo arrasan, pero también son abono de microorganismos, indicio de una vida. El fuego abrasa los cuerpos que el agua sólo puede conservar, pero el preciado fundamento al que se refiere Rabelais, cuando describe el parto escatológico de Gargantúa, es ahora el sexto elemento; un elemento impúdico descubierto en la Edad Media seguramente en oposición al otro gran descubrimiento aristotélico, el quinto elemento, el éter. Las heces (las cenizas) son la quintaesencia del grotesco, la suprema desacralización del fuego, su residuo más escatológico y su fuente profana de renovación (cfr. Fernández, 2004, pp. 222-223).

El Carnaval, como inframundo moral de los cuerpos entregados al pecado, crea un curioso infierno alegre, donde la vida renace de las cenizas. En palabras de Batjin "el infierno carnavalesco es la tierra que devora y procrea; muy frecuentemente se convierte en una cornucopia; las deformidades: vientres hinchados, grandes narices, jorobas, etc., son expresiones del embarazo y la virilidad" (Batjin, 2005, p. 86). Es posible que en el infierno se sufra, pero, a juzgar por las pinturas grotescas de El Bosco, los placeres infernales producen una fogosa fantasía erótica, donde la algarabía de cuerpos copula y se multiplica monstruosamente, gozando de vida, frescura y sensualidad.

\section{Fuego romántico, alquimia y resentimiento}

La cultura capitalista, de confesión protestante y calvinista, ha perdido muchas veces este sentido vitalista de lo infiernal. Quizá se deba a la reacción romántica (cristiana) que el infierno haya alienado su evidente dimensión lúdica y se haya ornado de fatalidad. En efecto, el Romanticismo se debate entre lo sublime y lo grotesco, acogiendo la tensión ascética entre lo elitista y lo popular, lo mórbido y lo vital, y por ello olvidando el carácter creativo, fecundo, de todo lo demoníaco.

El antihéroe grotesco, el asceta melancólico, es un déspota elitista, realmente cenizo, que condena el vitalismo del infierno popular. Se debe al escritor romántico y grotesco por excelencia, Victor Hugo, el más sublime retrato de este resentido sin vías de escape. En Nuestra Señora de París, 1831, el archidiácono de Notre Dame, Claude Frollo, es el prototipo de asceta constreñido, condenado a la sabiduría y a la 
inacción, que reprime sus bajos instintos sobre la bella gitana Esmeralda. La medicina antigua diría que Frollo coagula su bilis en un temperamento frío y descarnado, la bilis negra de los monjes, la célebre Melancholia (Panofsky, 2004, pp. 87-136). El asceta melancólico se opone al héroe colérico, del mismo modo que Frollo, en la novela de Hugo, es el anti-Aquiles, que aparece representado por Febo, un capitán de guardia bello y atlético, de quien se ha enamorado Esmeralda, y a quien Frollo intenta asesinar, abrasado por los celos y la envidia.

Pero Frollo tiene una pasión oculta, ligada a esta objeción de los placeres mundanos, la alquimia, la búsqueda del fuego secreto. El fuego alquímico ilumina al sabio medieval con su luz encarnada en oro, un fuego en estado concreto. "Si el diamante procede del carbón" según el personaje de Hugo "el oro procede del fuego" (Hugo, 2007, p. 213). Si el fuego sacro es espiritualista, el fuego alquímico es materialista, una quimera medieval que oscila entre la aspiración etérea (del asceta) y la posesión del preciado mineral (del avaro). Luego Frollo, el monje desprendido, sueña con poseer todo el oro del mundo, encarnado en el deseo de Esmeralda -aunque se ría del apetito grosero del populacho- y por ello el cura adopta a Quasimodo, el jorobado expósito, porque su figura grotesca alberga su oscura pasión: la misteriosa animación de la materia. Quasimodo, significa mas o menos, casi una forma, por eso el jorobado grotesco llega a confesar a Esmeralda, "mi desgracia es que me parezco demasiado a un hombre; me gustaría ser un animal del todo" (Hugo, 2007, p. 416). Por tanto, Quasimodo es la forma misma de la materia, como la materia prima, que viene del término egipcio Kêmia (alquimia). De modo que el asceta melancólico, que se comporta en la novela como una verdadera madre para Quasimodo, es el clérigo resentido de la catedral de Notre Dame -esa madre (mater) de piedra revestida por vidrieras multicolores. Frollo está fatalmente enamorado del fuego secreto, y de la materia embrujada de la alquimia, personificada en la gitana (egipcia) Esmeralda. Frollo desea penetrar la materia tanto como aquellos que, año tras año, condenan el Carnaval, aquello que repudia en público es lo que desea en privado.

\section{La quema y el entierro de la sardina}

De modo que la mitología clásica muestra a Prometeo transformando el fuego sagrado en fuego de cocina, y la mitología cristiana se debate entre el fuego secreto de la alta cultura, la alquimia de Frollo, y el fuego público de la baja cultura, el Carnaval. La alquimia, último brillo del fuego sagrado, fue la pasión de los ascetas, que se apagó progresivamente desde la Edad Media hasta la modernidad, sólo quedando ya las transubstanciaciones del fuego carnavalesco, herederas de los cultos dionisiacos, las saturnales romanas y las festividades agrícolas paganas. El Carnaval es el último rescoldo del fuego sagrado, la resaca de la eucaristía cristiana. Quizá por esta razón los festejos populares no buscan ya purificar los elementos, ni comprender su fórmula secreta, sólo los transforman, los travisten.

La mutación herética de los antiguos elementos consagrados busca la embriagadora trasgresión de su naturaleza incorrupta, mancillando su intacta identidad primera, y exponiendo al ridículo sus simbolismos. Igual que Baco convierte la sangre de los dioses en un vino de borrachos, sus secuaces dionisíacos transformaron el banquete 
de los sabios, con Sócrates a la cabeza, en una orgía de sexo y alcohol. Asimismo, el pueblo medieval travistió el pan y el vino de la eucaristía en infinidad de comidas y bebidas heréticas, entre las que destaca El entierro de la Sardina como una parodia totémica de la Muerte y Resurrección de Cristo.

En la cultura cristiana el pez destaca como animal que simboliza a Cristo Eucarístico. Debemos a medievalista Charbonneau-Lassay el inventario más completo dedicado a las metamorfosis animales de Cristo (Charbonneau-Lassay, 1997, pp. 687-713). A parte de la procedencia conjunta del pez (ichthys) y el nombre de Cristo (Christi) el Evangelio se refiere al Mesías como un pescador de hombres. El hijo de Dios tiene la destreza de multiplicar los panes y los peces, el símbolo del pez era el pasaporte de la comunidad cristiana oculta en las catacumbas romanas. Por otra parte, la pantomima del pez reducido a cenizas tiene que ver con una epifanía burlesca del Ave-fénix, que en el imaginario medieval era otro símbolo de Cristo entendido como Resurrección de la Carne o palingenesia. El Ave Fénix era un pájaro mitológico con forma de garza o faisán, que lucía una cresta encopetada, y cuyo nombre significaba Pájaro de Fuego, un emblema de la eternidad que aludía a la regeneración perfeccionada del hombre tras su muerte. Charbonneau-Lassay legó una completa iconología del Ave Fénix, desde su origen egipcio hasta su acepción cristiana donde, "renacido de sus cenizas, bajo el ardor de los rayos del sol y el abrasamiento perfumado de las plantas aromáticas, tenía que ser una de las más hermosas joyas de la corona emblemática de Cristo" (Charbonneau-Lassay, 1997, pp. 405-422).

Luego el Entierro de la Sardina es una apostasía del animal totémico, en la figura del Pez-Fénix de Carnaval, parodia grotesca del Cristo Eucarístico (pez) y Resurrecto (Ave-Fénix). Una suerte de cadáver exquisito que aúna dos de las más profundas alegorías de Cristo, pero sometidas al simbolismo herético del fuego grotesco y las cenizas pútridas. Sin duda, la quema de la Sardina se mofa de la inmolación sagrada del animal totémico, es decir, de su ascensión al cielo en forma de aroma santuario, una burla que termina con la raspa del pez, chamuscada y cenicienta (o podrida) que se puede emparejar a la osamenta descarnada que Prometeo entregó a Zeus. De tal manera que a la purificación del fuego siempre sucede la escatología de las cenizas en un ciclo que no es el natural, sino el histórico. El esquema doble del Pez-Fénix se compone, por tanto, del lado vitalista y mórbido de la cultura. La carne eucarística, inmolada en el fuego de cocina, se trasmuta en el ave palingenésica, transformado en ceniza rediviva. Según el mitoanálisis de Lévi-Strauss en este proceso de creación a partir de la destrucción, las cenizas del pez actuarían como excrementos que abonan la tierra donde el pez es sepultado. Finalmente actuarían como las heces animales, nutriendo la tierra baldía del campesino, quien cada año reclama a los dioses el Renacimiento de la fertilidad.

\section{Las cenizas de la trasgresión}

El Miércoles de Ceniza se recrea el enterramiento de los restos de la Sardina, un prolegómeno herético de la Encarnación. El milagro de la fertilidad de la Madre Tierra coincide con los esponsales de la Virgen anunciado por ángel Gabriel, el 25 de Marzo, al recomienzo del ciclo cristiano. Por eso, de entre todas las variaciones de la Quema 
de la sardina las más jugosa es aquella en la que el pez totémico es enterrado en el agua. Pero esta versión acuática del rito campesino no deja de incidir en la escatología de lo podrido, pues para Lévi-Strauss es tan pútrida la carne chamuscada (cenicienta) como la encharcada (mohosa). Muchas culturas costeras o ribereñas sumergen los restos de la Sardina en una canoa abandonada a la Segunda Muerte (el mar, el olvido, etc). La travesía acuática de la Sardina es otra sublimación herética de la Resurrección, pues las cenizas recobrarán vida, inmersas en el elemento primordial del pez, antes de sufrir nuevamente la inmolación del fuego. Ritual tantas veces asociado al ostracismo del tradicional abandono de un cuerpo en una canoa sin aparejos, con el viajero atado de pies y manos. Este mismo castigo es infligido por muchas comunidades primitivas sobre ciertos sujetos impuros que acaban abandonados a su suerte en un esquife agujereado. ¿Quién sabe si el vagar de Ulises por ultramar es la cara más sublime del ostracismo, la peor calamidad imaginable para el pueblo griego? ¿Acaso no fue Ulises errado en el mar por ofender a los dioses, cuando su tripulación osó comer la carne tabuada de unas reses sagradas?

La quema y posterior entierro de la Sardina es, por tanto, el sacrilegio mayor del mito de la Encarnación, allí donde se visualiza con más vehemencia la risa del fuego, su potencial sacrílego, quizá en la raspa consumida como una sonrisa dentada. Ya lo dijo Bajtin, la risa degrada y materializa (Batjin, 2005, p. 25). La risa arrasa con todo, cuestiona todas las jerarquías, reduce a cenizas los valores más sagrados. En la Edad Media la risa estaba generalmente prohibida: era sólo un lujo permitido durante los días festivos. Y no cabe duda que el sacrilegio de la Sardina se condena por los sublimes eruditos precisamente porque se rodea de las risotadas del pueblo.

Es preciso volver a la literatura para terminar poniendo en su lugar de dónde viene esta condenación ascética de la risa de Carnaval. Umberto Eco en El nombre de la rosa (1980) retrató a Fray Jorge de Burgos, caricatura de Jorge Luis Borges, como un monje erudito, encargado de custodiar la gran biblioteca laberíntica de la abadía, símbolo de todo el saber de la cristiandad. La cultura clásica parece estar a resguardo en manos del severo monje invidente, toda menos un libro, el mítico Tratado sobre la risa, del desaparecido libro segundo de Aristóteles, dedicado a la comedia. Fray Jorge llegará a asesinar a todo monje que ose leer el libro maldito, con el astuto sistema de envenenar sus páginas. La explicación es sencilla, el Filósofo es el destructor de la cristiandad, el conversor de la teología en Historia Natural. En su cruzada medieval contra la comedia, Fray Jorge considera la risa la degradación suprema del hombre, que deforma sus facciones y contorsiona su cuerpo de manera grotesca. Pero Fray Jorge no tiene miedo a la risa de Carnaval, la herejía de los simples, porque es la distracción del campesino, la licencia del borracho: "Incluso la Iglesia, en su sabiduría, ha permitido el momento de la fiesta, del carnaval, de la feria, esa polución diurna que permite descargar los humores y evita que se ceda a otros deseos y ambiciones" (Eco, 2000, pp. 473-476). 


\section{La risa del fuego}

Fray Jorge sabe que la risa carnavalesca está controlada por la resaca del orden civil, el control de los cuerpos ebrios después de la fiesta. Pero la risa de Aristóteles es diferente. La comedia puede llegar a ser la chispa de la revolución intelectual, que se expresa arrasando todo el sistema teológico. Empleando la comedia y la sátira como medicinas del alma, Aristóteles abre las puertas a la destrucción de la Fe. Con la sabiduría peripatética el hombre sería capaz de sanar a carcajadas. Finalmente se podría redimir lo alto a través de la emancipación de lo bajo. El peligro que El tratado de la risa supone para Fray Jorge consistiría en la nueva y catártica aspiración a destruir la muerte a través de la emancipación del miedo. Advierte Fray Jorge:

"Si algún día alguien, esgrimiendo las palabras del Filósofo y hablando, por tanto, como filósofo, elevase el arte de la risa al rango de arma sutil, si la retórica de la convicción es reemplazada por la retórica de la irrisión, ya no como excepción plebeya, sino como ascesis del docto, confiada al testimonio indestructible de la escritura, si el arte de la irrisión llegara a ser aceptable, y pareciera noble y liberal, y ya no mecánica, si algún día alguien pudiese decir; «Me río de la Encarnación...» Entonces no tendríamos armas para detener la blasfemia, porque apelaría a las fuerzas oscuras de la materia corporal, las que se afirman en el pedo y el eructo". (Eco, 2000, pp. 473-476)

Pues bien, esto que tanto temía el franciscano sucede en cada Carnaval con la Quema y el posterior entierro de la sardina, cuando el pueblo se ríe fogosamente del misterio de la Encarnación, el pilar ideológico de la filosofía cristiana occidental. Durante el Carnaval nos reímos de la muerte del mismo modo que la risa del fuego consume desde dentro la palabra mítica. Y esto sucede tanto en la calle como en los museos. ¿No es el fuego, considerado como una de las Bellas Artes, el modo de expresión grotesco más extendido en el arte contemporáneo? ¿No son los artistas los antiguos bufones y payasos, que como la fiesta de los tontos (festa estultorum) se reúnen cada año en la feria de arte, siempre coincidente con el Carnaval, para desacralizar el gusto bienpensante con sus obras obscenas y su lenguaje provocador?

Cuando ha sido desplazado el fuego desde la pira sagrada, en la que ardía como elemento ascético de purificación, para llegar a los museos donde finalmente arde como fuego fatuo en manos de artistas poseídos por un gusto carnavalesco, el fuego ríe más alto que nunca. Es cierto que los artistas son muchas veces bufones de corte, seres grotescos que adulan su propio ombligo mientras orinan sobre las instituciones pero el ritual pirómano del arte y la coprofilia del gusto reportan también grandes enseñanzas: el poder emancipador de la risa, la risa que ha consumido la palabra tiránica de los dioses. 


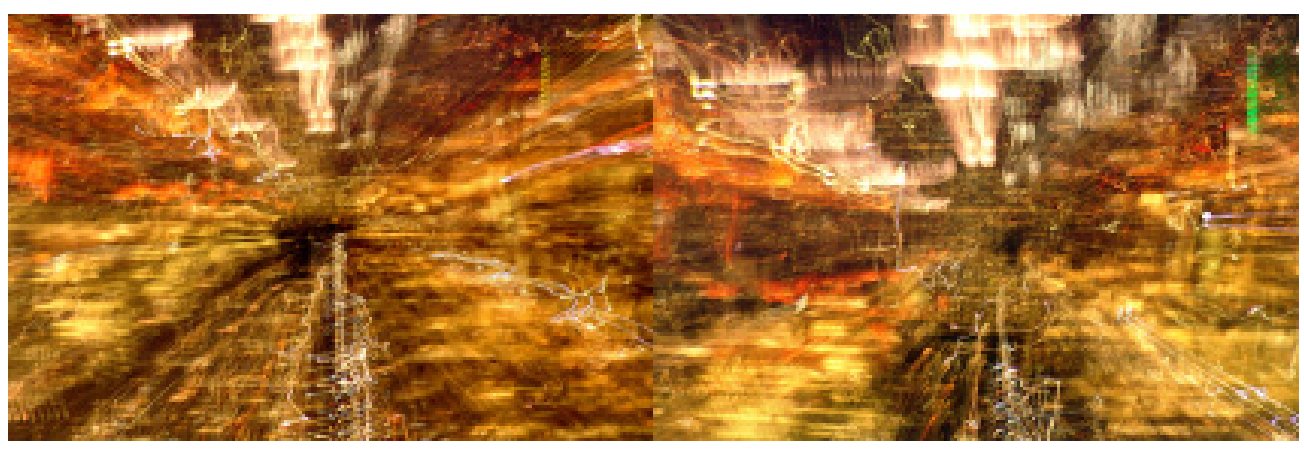

Figura 2. Vicente Alemany: Nueva York. (La risa del Fuego). 2011

Este artículo se ha desarrollado a partir de la línea de investigación teórica y plástica emprendida por los autores en 2008 sobre el imaginario material en el arte contemporáneo. Se puede consultar en el texto Genealogías del Arte Contemporáneo (Akal, Bellas Artes, 2011).

\section{Referencias}

Bachelard, G. (1949) La psychanalyse du feu, París, Gallimard, 2005.

Bajtin, M. (1965) La cultura popular en la Edad Media y en el Renacimiento, ed. Alianza, Madrid, 2005.

Caillois, R. (1939) El hombre y lo sagrado, ed. FCE, México, 1996.

Charbonneau-Lassay, I. (1946) El bestiario de Cristo. El simbolismo animal en la Antigüedad y la Edad Media, ed. J. J. Olañeta, Barcelona, 1997.

Eco, U. (1980) El nombre de la rosa, ed. Lumen, Barcelona, 2000.

Fernández, B. (2004) De Rabelais a Dalí. La imagen grotesca del cuerpo, ed. PUV, Valencia.

Frazer, J. G. (1930) Mythes sur l'origine du feu, ed. Payot, 2009.

Freud, S. (1913) Tótem y tabú, ed. Biblioteca Nueva, Madrid, 1996.

Harpur, P. (2005) El fuego secreto de los filósofos, ed. Atalanta, Madrid, 2005.

Hesiodo, Teogonía, ed. Alianza, Madrid, 1994.

Homero, Ilíada, ed. Cátedra, Madrid, 1997.

Hugo, V. (1831) Nuestra Señora de París, ed. Cátedra, Madrid, 2007.

Panofsky, E. (1964) Saturno y la melancolía, ed. Alianza, Madrid, 2004.

J. L. Pardo (1997) La carne de las máquinas, ed. CAAM, Las Palmas.

Rabelais, F. (1535) Gargantúa, ed. Cátedra, Madrid, 1999.

Repollés, J. (2011) Genealogías del arte contemporáneo, ed. Akal Bellas Artes, Madrid. 